DOI: $10.19195 / 0137-1134.119 .18$

\title{
KRZYSZTOF URBANIAK
}

ORCID: 0000-0002-0735-8924

Uniwersytet im. A. Mickiewicza w Poznaniu

\section{RADA SĘDZIOWSKA ORAZ KOMISJA NOMINACYJNA DLA ANGLII I WALII}

\begin{abstract}
Abstrakt: Władza sądownicza Zjednoczonego Królestwa jest fenomenem w skali europejskiej. Mimo że rola sędziów w systemie common law była znacznie większa niż w systemach prawa kontynentalnego, to brakowało w ustroju brytyjskim formalnych, instytucjonalnych zabezpieczeń niezależności sądów i niezawisłości sędziów. Zasadę tę postrzegano jako konwenans konstytucyjny. Rada Sędziowska, będąca reprezentacją środowiska sędziowskiego, miała jedynie status organu wewnętrznego sądownictwa i pełniła funkcję doradczą wobec Lorda Naczelnego Sędziego. Wprowadzone na początku XX wieku reformy wymiaru sprawiedliwości, w tym ustanowienie Komisji Nominacyjnej, niewątpliwie wpłynęły na umocnienie niezależności sądów wobec egzekutywy i zwiększyły wpływ środowiska sędziowskiego na obsadzanie urzędów sędziowskich w Anglii i Walii.
\end{abstract}

Słowa kluczowe: Rada Sędziowska dla Anglii i Walii, Komisja Nominacyjna dla Anglii i Walii, władza sądownicza, niezależność sądów

Władza sądownicza Zjednoczonego Królestwa jest fenomenem w Europie. Jej współczesny kształt to wypadkowa wielu czynników, takich jak między innymi odmienność i ewolucyjny rozwój kultury prawnej, pragmatyzm w tworzeniu i przekształcaniu instytucji prawnych, diametralnie różna od kontynentalnej tradycja tworzenia źródeł prawa, brak konstytucji pisanej, udział elementu społecznego w wymiarze sprawiedliwości oraz centralna rola sędziego w kształtowaniu prawa $^{1}$. Na szczególną uwagę zasługuje ostatni z wymienionych czynników. Rola sędziów w systemie common law jest znacznie większa niż w systemach prawa kontynentalnego ${ }^{2}$. W doktrynie prawa common law dominuje pogląd, że sędziowie

${ }^{1}$ K. Urbaniak, Zasady podziału władzy w Wielkiej Brytanii, [w:] Zasady podziału władzy we wspótczesnych państwach europejskich, red. S. Grabowska, R. Grabowski, Rzeszów 2016, s. 98.

2 G.P. Wilson, Angielski sędzia, [w:] Problemy prawa angielskiego i europejskiego oraz reformy w Europie Środkowej (Polska, Wegry), red. K. Nowacki, („Prawo” 272), Wrocław 2000, s. 65 n.; E.M. Salzberger, A positive analysis of the doctrine of separation of powers, or: Why do we have an independent judiciary?, „International Review of Law and Economics” 13, 1993, s. 349-379. 
nie tylko odkrywają prawo, to znaczy deklarują, co było i nadal jest prawem, lecz także je tworzą, to jest reinterpretują lub rozszerzają stare reguły prawne oraz kreują nowe ${ }^{3}$. W angielskim common law sędziowie zatem zarówno wykonują władzę sądowniczą, jak i, w pewnym zakresie, pełnią funkcję prawotwórczą. Prawotwórcza rola sędziów przybiera dwie zasadnicze formy. Pierwszą z nich jest kreowanie precedensów przy rozstrzyganiu konkretnych spraw. Druga forma polega na interpretowaniu prawa pisanego ${ }^{4}$. Sądy nie są władne orzekać o ważności ustaw uchwalanych przez parlament, aczkolwiek mają takie uprawnienie w stosunku do ustawodawstwa delegowanego. Zadaniem sądów jest natomiast interpretowanie prawa stanowionego, gdy sporne jest znaczenie danego aktu prawnego ${ }^{5}$.

\section{SYSTEM PRAWNY ZJEDNOCZONEGO KRÓLESTWA}

Na system prawny Zjednoczonego Królestwa Wielkiej Brytanii i Irlandii Północnej składają się trzy systemy: system prawny Anglii i Walii, system prawny Szkocji oraz system prawny Irlandii Północnej. Każda z tych trzech jurysdykcji ma własny system prawa karnego, a Szkocja także oddzielny system sądownictwa cywilnego. Najwyższym organem sądowym w Zjednoczonym Królestwie jest obecnie Sąd Najwyższy (Supreme Court). Rozpatruje on środki zaskarżenia bądź za zgodą sądu, którego orzeczenie jest kwestionowane, bądź za własną zgodą (leave $)^{6}$. W wypadku spraw karnych zgoda na orzekanie przez Sąd Najwyższy może być wydana tylko jeśli sąd, od którego orzeczenia składany jest środek odwoławczy, potwierdzi, że w sprawie występuje problem prawny o znaczeniu publicznym i sprawa powinna być rozpatrywana przez Sąd Najwyższy

Funkcjonujący w Zjednoczonym Królestwie system sądownictwa w ciągu wieków przechodził wiele przeobrażeń strukturalnych. W latach 1873 i 1875 w Wielkiej Brytanii przeprowadzono gruntowną reformę sądów, znosząc różnice między sądami stosującymi common law a sądami stosującymi tak zwane zasady słuszności (equity) ${ }^{8}$. Do 2009 roku najwyższym organem sądowym Zjednoczonego

3 K. Banasik, Przyszłość angielskiego prawa karnego, „Prokuratura i Prawo” 2013, nr 10, s. 126; J. Martin, The English Legal System, London 2007, s. 37; P. Shears, G. Stephenson, James' Introduction to English Law, Oxford 2006, s. 14-15; G. Slapper, D. Kelly, The English Legal System, London 2004, s. 108; S.H. Bailey, J.P.L. Ching, N.W. Taylor, Smith, Bailey and Gunn on The Modern English Legal System, London 2007, s. 474 n.

4 A.W. Bradley, D.K. Ewing, C.J.S. Knight, Constitutional and Administrative Law, London 2018, s. 16-19.

5 Ibidem, s. 17.

${ }^{6}$ P. Biskup, P. Mikuli, Zjednoczone Królestwo Wielkiej Brytanii i Irlandii Pótnocnej, [w:] Status prawny sędziego we współczesnych systemach politycznych, red. P. Mikuli, Koszalin-Gdańsk 2013, s. 33.

7 Ibidem.

8 Ibidem, s. 31. 
Królestwa była Izba Lordów ${ }^{9}$. Uprawnienia sądowe Izby Lordów wywodziły się z instytucji Sądu Królewskiego. Do połowy XIX wieku Izba Lordów wykonywała swoje kompetencje sądowe w pełnym składzie niezależnie od swojej funkcji ustawodawczej ${ }^{10}$. W 1844 roku ukształtował się konwenans konstytucyjny, na mocy którego lordowie niemający przygotowania prawniczego nie brali udziału w orzekaniu. W 1876 roku wprowadzono instytucję lordów apelacyjnych (Lords of Appeal in Ordinary). Tytuł ten mogły otrzymać osoby legitymizujące się co najmniej dwuletnim stażem na wysokim stanowisku sędziowskim lub wykonujące zawód adwokata przez co najmniej 15 lat $^{11}$. W 1948 roku funkcje sądownicze Izby Lordów przejął Komitet Apelacyjny Izby Lordów (Appellate Committee of the House of Lords).

Na mocy ustawy The Constitutional Reform Act z 2005 roku dokonano bardzo głębokiej reformy władzy sądowniczej. Celem było zbliżenie rozwiązań brytyjskich w zakresie sądownictwa do standardów funkcjonujących w innych państwach demokratycznych ${ }^{12}$. Ustawa wprowadziła ustawowe zabezpieczenia w zakresie niezależności i niezawisłości sędziów ${ }^{13}$, eliminowała historycznie uwarunkowane zakłócenia podziału władz między judykatywą a pozostałymi organami władz państwowych (ustanowienie Sądu Najwyższego i reforma urzędu Lorda Kanclerza) ${ }^{14}$.

Najdonioślejszym elementem reformy z 2005 roku było odebranie Izbie Lordów (Komitetowi Apelacyjnemu Izby Lordów) tradycyjnych uprawnień sądowych i utworzenie Sądu Najwyższego. W wyniku tego zabiegu zapewniono odrębność organizacyjną i personalną najwyższej instancji sądowniczej od parlamentu. Utworzony w 2009 roku Sąd Najwyższy składa się z 12 sędziów, a do jego pierwszego składu weszli dotychczasowi lordowie apelacyjni wyłączeni na mocy ustawy ze składu Izby Lordów. Ustawa przewiduje, że sędziów Sądu Najwyższego będzie powoływać monarcha za radą premiera ${ }^{15}$. Sąd Najwyższy przejął dotychczasowe kompetencje sądowe Izby Lordów. Mianowicie: rozpatruje apelacje w sprawach cywilnych i karnych od orzeczeń Sądu Apelacyjnego Anglii i Walii oraz od orzeczeń

9 The Judicial House of Lords 1876-2009, red. L. Blom-Cooper, B. Dickson, G. Drewry, Oxford 2011.

10 P. Biskup, P. Mikuli, op. cit., s. 32; G. Drewry, L. Blom-Cooper, The Appellate Function, [w:] The House of Lords. Its Parliamentary and Judical Roles, red. B. Dickson, P. Carmichael, Oxford 1999, s. 113.

11 P. Biskup, P. Mikuli, op. cit., s. 32.

12 A. Le Sueur, The Conception of the UK's New Supreme Court, [w:] Building the UK's New Supreme Court. National and Comparative Perspectives, red. A. Le Sueur, Oxford 2004.

13 Szerzej zob. G. Gee et al., The Politics of Judicial Independence in the UK's Changing Constitution, Cambridge 2015.

14 P. Mikuli, Reformy sądownictwa w Zjednoczonym Królestwie w latach 2005-2009, [w:] B.H. Troszek, T. Czapiewski, Od Thatcher do Blaira. Wielka Brytania na przetomie XX $i$ XXI wieku, Szczecin 2010, s. 85; A. Michalak, Pierwsze pięć lat działalności Sądu Najwyższego Zjednoczonego Królestwa Wielkiej Brytanii i Irlandii Pótnocnej, „Przegląd Sejmowy” 2015, nr 2, s. 120 n.; A. Kelso, Parliamentary Reform at Westminster, Manchester 2009, s. 155 n.

15 Na temat organizacji Sądu Najwyższego zob. A. Michalak, op. cit., s. 128 n. 
Sądu Apelacyjnego Irlandii Północnej, rozpatruje apelacje w sprawach cywilnych od orzeczeń Sądu Naczelnego Szkocji, rozpatruje apelacje w ograniczonym zakresie od orzeczeń Wysokiego Sądu Anglii i Walii oraz Wysokiego Sądu Irlandii Północnej, a także rozpatruje apelacje od orzeczeń Wojskowego Sądu Apelacyjnego. Oprócz kompetencji do orzekania w sprawach apelacyjnych Sądowi Najwyższemu powierzono też rozstrzyganie sporów kompetencyjnych pojawiających się na tle funkcjonowania organów regionalnych utworzonych w procesie dewolucji ${ }^{16}$.

Nie mniej symboliczną zmianą wprowadzoną ustawą z 2005 roku była gruntowna reforma urzędu Lorda Kanclerza. Lord Kanclerz łączył w sobie funkcje należące do trzech różnych władz: ustawodawczej, wykonawczej i sądowniczej. Był przewodniczącym Izby Lordów, prezesem dawnego Sądu Najwyższego Anglii i Walii, szefem Wydziału Kanclerskiego i sędzią Sądu Apelacyjnego, przewodniczącym Komitetu Apelacyjnego Izby Lordów, członkiem Komitetu Sądowego Tajnej Rady oraz ministrem wchodzącym w skład gabinetu odpowiedzialnym za szeroko rozumiany wymiar sprawiedliwości ${ }^{17}$. Oprócz tego Lord Kanclerz miał szerokie kompetencje w dziedzinie nominacji sędziów oraz inspekcyjne wobec niektórych instytucji, które wykonywał w imieniu monarchy ${ }^{18}$. Ustawa pozbawiła Lorda Kanclerza jego uprawnień sądowych oraz prawa do przewodniczenia obradom Izby Lordów, tworząc nowy urząd Spikera Izby. Lord Kanclerz pozostał organem władzy wykonawczej odpowiedzialnym za funkcjonowanie wymiaru sprawiedliwości.

Ustawa zreformowała również procedury nominacyjne sędziów. Wprowadzone zmiany miały na celu zobiektywizowanie kryteriów oceny kandydatów na sędziów i osłabienie wpływu władzy wykonawczej na proces obsadzania urzędów sędziowskich. W celu wzmocnienia kryterium merytorycznego w procesie nominowania sędziów ustawa powołała do życia komisje nominacyjne składające się między innymi z przedstawicieli władzy sądowniczej ${ }^{19}$. Innym elementem reformy była zmiana procedur dotyczących odpowiedzialności dyscyplinarnej sędziów i ich usunięcia z urzędu. Wprowadzone zmiany zredukowały rolę parlamentu w procedurze usunięcia sędziego do wymiaru czysto formalnego ${ }^{20}$.

\section{STRUKTURA SĄDOWNICTWA ANGLII I WALII}

Sądownictwo Anglii i Walii ma bardzo złożoną i niejednolitą strukturę, będącą wynikiem wielowiekowych przekształceń i reform. Najniższy szczebel sądow-

16 Ibidem, s. 87.

17 D. Oliver, Constitutionalism and the abolition of the Office of Lord Chancellor, „Parliamentary Affairs" 2004, nr 4, s. 754 n.

18 P. Mikuli, Reformy sadownictwa..., s. 87-88.

19 P. Biskup, P. Mikuli, op. cit., s. 38 n.

20 P. Mikuli, Reformy sądownictwa..., s. 90-96. 
nictwa tworzą tak zwane sądy niższej instancji. Co ciekawe, są one odrębne dla spraw cywilnych i karnych. Najniższym szczeblem struktury karnego wymiaru sprawiedliwości w Anglii i Walii są sądy pokoju (tak zwane magistrates courts). Na obszarze Anglii i Walii jest ich około 330, a ich rozmieszczenie koresponduje w przybliżeniu z siatką okręgów policyjnych i prokuratur. Sądy pokoju działają na podstawie ustawy The Magistrates' Courts Act z 1980 roku. Rozpatrują one okoto $95 \%$ wszystkich spraw karnych, zazwyczaj o przestępstwa mniejszej wagi (tak zwane summary offences) oraz $\mathrm{w}$ ramach procedury uproszczonej i przyspieszonej. Sądy pokoju są też właściwe do pewnych kategorii najprostszych spraw cywilnych oraz w sprawach dla niepełnoletnich ${ }^{21}$. W sądach tych orzekają przeważnie osoby bez wykształcenia prawniczego. W poważniejszych sprawach karnych, skomplikowanych pod względem stanu faktycznego bądź prawnego, orzeka zawodowy sędzia rejonowy (District Judge ${ }^{22}$. W najpoważniejszych sprawach karnych sądem pierwszej instancji jest Sąd Koronny (Crown Court), który zaliczany jest do tak zwanych sądów wyższej instancji (senior courts).

Najniższym szczeblem wymiaru sprawiedliwości w sprawach cywilnych w Anglii i Walii jest Sąd Hrabstw (County Court). Obejmuje on całą Anglię i Walię. Ustanowiono go w 2014 roku w wyniku przekształcenia w jednolity sąd istniejących wcześniej sądów hrabstw ${ }^{23}$. Zajmuje się on większością (poza najbardziej skomplikowanymi) spraw cywilnych w Anglii i Walii, z wyłączeniem spraw z zakresu prawa rodzinnego. Od decyzji sądów hrabstw przysługuje odwołanie do właściwego wydziału Wysokiego Trybunału (High Court). Osobną kategorią sądu niższej instancji jest utworzony w 2014 roku Sąd Rodzinny (Family Court), właściwy w sprawach rodzinnych (rozwody, opieka nad dziećmi, obowiązki alimentacyjne, adopcja).

Do kategorii sądów niższej instancji zalicza się również trybunały (tribunals). Rozpoznają one rozmaite sprawy o niskim ciężarze gatunkowym, dotyczące na przykład zdrowia psychicznego, nieruchomości, zasiłków czy zatrudnienia. Trybunały są de facto quasi-sądami, ale od ich orzeczeń, w zależności od trybunału rozpatrującego sprawę, można się odwoływać do trybunału wyższej instancji (upper tribunal) lub sądu.

Do tak zwanych sądów wyższej instancji zaliczamy: Sąd Koronny, Wysoki Trybunał oraz Sąd Apelacyjny (Court of Appeal). Sąd Koronny rozpoznaje najczęściej sprawy karne, ale ma także ograniczoną właściwość przedmiotową w niektórych sprawach cywilnych. Formalnie jest to jeden sąd, ale funkcjonuje ponad 70 jego oddziałów terenowych. Zazwyczaj rozprawy przez sądem koron-

${ }^{21}$ Szerzej zob. B. Gibson, M. Watkins, The Magistrates' Court: An Introduction, Winchester 2009; H. Riddle, R. Zara, Essential Magistrates' Court Law, Winchester 2019.

22 C. Michalczuk, Struktura sadownictwa karnego w Wielkiej Brytanii, „Prokuratura” 2005, nr 7-8, s. 181.

23 P. Mikuli, Sadownictwo w Zjednoczonym Królestwie. Wybrane zagadnienia ustrojowe, Kraków 2019, s. 65. 
nym odbywają się w składzie jednego sędziego, z udziałem dwunastoosobowej ławy przysięgłych (jury). W drugiej instancji Sąd Koronny rozpatruje apelacje od wyroków sądów magistrackich.

Wysoki Trybunał kierowany jest przez Lorda Najwyższego Sędziego Anglii i Walii (Lord Chief Justice of England and Wales). Trybunał powstał w 1875 roku na mocy ustawy The Judicature Acts z 1873 roku. Podzielony jest na trzy wydziały: Wydział Ławy Królewskiej (Queen's Bench Division), Wydział Kanclerski (Chancery Division) oraz Wydział Rodzinny (Family Division). Wydział Ławy Królewskiej zajmuje się szerokim zakresem spraw cywilnych, w tym powództwami o odszkodowanie wynikającymi z niedotrzymania umów oraz odpowiedzialności deliktowej, sprawami o ochronę dóbr osobistych i zniesławienie, sporami o charakterze handlowym oraz sprawami z zakresu prawa morskiego. W 2000 roku w ramach Wydziału Ławy Królewskiej wyodrębniono specjalną jednostkę — Sąd Administracyjny, który rozpatruje sprawy z zakresu administracji publicznej, w ramach odrębnej procedury ${ }^{24}$. Wydział Kanclerski zajmuje się między innymi rozstrzyganiem spraw majątkowych, testamentami, spadkami, patentami oraz własnością intelektualną, a także sporami dotyczącymi spółek kapitałowych i osobowych. Wydział Rodzinny z kolei rozpatruje sprawy z zakresu prawa rodzinnego, a więc rozwody, podział majątku między małżonkami, ustalenie opieki nad dzieckiem oraz sprawy alimentacyjne. Wysoki Trybunał pełni dwie podstawowe funkcje. Po pierwsze, jest sądem pierwszej instancji dla spraw o wyższej wartości przedmiotu sporu oraz dla spraw o większym ciężarze gatunkowym. Po drugie, stanowi instancję odwoławczą od orzeczeń cywilnych zapadłych w sądach niższego rzędu sądach hrabstw i rodzinnych oraz od niektórych orzeczeń trybunałów. W zakresie sądownictwa karnego rozpatruje apelacje od orzeczeń sądów pokoju oraz rzadziej sądów koronnych, które zapadły z naruszeniem prawa, naruszeniem przepisów o właściwości oraz w których pojawiło się zagadnienie prawne budzące poważne wątpliwości (Wydział Ławy Królewskiej) ${ }^{25}$.

Najważniejszym i najwyższym sądem wyższej instancji sądownictwa Anglii i Walii jest Sąd Apelacyjny (Court of Appeal). Składa się on z dwóch wydziałów Karnego i Cywilnego. Wydziałowi Karnemu przewodniczy Lord Naczelny Sędzia (Lord Chief Justice), będący jednocześnie zwierzchnikiem wymiaru sprawiedliwości w Anglii i Walii. Wydział Karny rozpoznaje środki zaskarżenia na podstawie kilku ustaw, choć najczęściej są to apelacje od wyroków Sądu Koronnego. Może on zmienić lub utrzymać wyrok albo zwrócić sprawę do ponownego rozpoznania. Wydział Cywilny, kierowany przez Mistrza Rejestru (Master of the Rolls), trzeciego rangą sędziego Anglii i Walii, rozpoznaje odwołania głównie od orzeczeń Wysokiego Trybunału oraz Sądu Hrabstw. Podobnie jak w sprawach karnych sąd może zmienić lub utrzymać wyrok albo zwrócić sprawę do ponownego rozpoznania ${ }^{26}$.

24 P. Biskup, P. Mikuli, op. cit., s. 33.

25 C. Michalczuk, Struktura sądownictwa..., s. 185.

26 P. Mikuli, Sądownictwo w Zjednoczonym Królestwie..., s. 67 n. 
Najwyższym organem sądowym w Zjednoczonym Królestwie, będącym jednocześnie sądem odwoławczym najwyższej instancji w sprawach karnych i cywilnych dla Anglii i Walii, jest Sąd Najwyższy (Supreme Court of the United Kingdom). Na mocy ustawy The Constitutional Reform Act z 2005 roku od 2009 roku przejął on funkcje Komisji Apelacyjnej Izby Lordów (Appellate Committee of the House of Lords). Zgodę na wniesienie do Sądu Najwyższego środka zaskarżenia wydaje się tylko wówczas, gdy dotyczy on kwestii prawnych istotnych dla społeczeństwa lub państwa.

\section{RADA SĘDZIOWSKA - GENEZA I KOMPETENCJE}

Cechą charakterystyczną rad sędziowskich w systemach prawnych Zjednoczonego Królestwa jest nieuregulowanie ich statusu przez ustawodawstwo. Z tego punktu widzenia umocowanie ustrojowe tych rad jest relatywnie słabe, gdyż funkcjonują one wyłącznie na podstawie decyzji osób pełniących funkcje szefów sądownictwa w poszczególnych krajach Zjednoczonego Królestwa ${ }^{27}$. Mocnego oparcia ich funkcjonowania należy również szukać w poszanowaniu dorobku kultury prawnej oraz wielowiekowej tradycji niezależności władzy sądowniczej. Jedynie Rada Sędziowska Anglii i Walii (Judges' Cuncil) została wzmiankowana w akcie rangi ustawowej, to jest The Constitutional Reform Act z 2005 roku. Ustawa ta nie reguluje statusu rady, jej składu czy kompetencji, traktując ją jako instytucję zastaną. Stanowi jedynie, że rada jest organem wyznaczonym przez Lorda Naczelnego Sędziego oraz przyznaje jej kompetencję do wskazywania dwóch członków Komisji do spraw Nominacji Sędziowskich.

Rada Sędziowska powstała w 1873 roku na mocy ustawy The Judicature Acts z 1873 roku. Funkcjonowała ona nieprzerwanie w ustalonej w XIX wieku formule do 1981 roku. Rada została powołana do życia ponownie w 1988 roku w wyniku sugestii kierowanych ze środowisk naukowych i sądowych ${ }^{28}$. Na jej czele stanął Lord Naczelny Sędzia, jej członkami zaś zostali przedstawiciele sądów wyższych instancji. Jako główny cel jej działalności wskazywano reprezentację środowiska sędziowskiego wobec innych organów władzy, stanie na straży niezawisłości sądów oraz zapewnienie współpracy między władzą sądowniczą a wykonawczą ${ }^{29}$. W 2002 roku Rada przyjęła swoją konstytucję, precyzując cele działania oraz poszerzając swój skład o przedstawicieli wszystkich szczebli sądownictwa. W 2006 roku

27 P. Mikuli, Rady sadownictwa w Zjednoczonym Królestwie — zarys pozycji ustrojowej, [w:] Konstytucjonalizm - doktryny — nauki polityczne. Księga dedykowana Profesorowi Andrzejowi Ziębie, red. R. Kłosowicz et al., Kraków 2016, s. 568.

28 Zob. I. Scott, The Council of Judges in the Supreme Court of England and Wales, „Public Law" 1989, s. 379 n.

29 J. Thomas, The Judges Council, „Public Law” 2005, s. 621 n. 
Rada dokonała gruntownej rewizji swojej konstytucji, dostosowując ją do zmian wynikających z przyjęcia ustawy The Constitutional Reform Act z 2005 roku.

Rada jest ciałem reprezentującym sądownictwo Anglii i Walii. Doradza ona Lordowi Naczelnemu Sędziemu, będącemu zwierzchnikiem wymiaru sprawiedliwości Anglii i Walii. Rada prowadzi konsultacje oraz przedstawia opinie i analizy w sprawach dotyczących funkcjonowania i organizacji wymiaru sprawiedliwości. Zgodnie z postanowieniami konstytucji celami Rady są:

— zachowanie niezależności sądownictwa;

— ochrona i zapewnienie prawidłowego funkcjonowania wymiaru sprawiedliwości;

— koordynowanie poglądów i działań sędziów zmierzających do tych celów; liwości;

- promowanie zawodowych interesów przedstawicieli wymiaru sprawied-

— udzielanie wskazówek sędziom w kwestiach etycznych i innych sprawach mających znaczenie dla prawidłowego funkcjonowania wymiaru sprawiedliwości;

- ułatwianie komunikacji między różnymi szczeblami sądownictwa;

— doradzanie oraz informowanie Lorda Naczelnego Sędziego o poglądach władzy sądowniczej w sprawach należących do jego obowiązków;

— zajmowanie się wszystkimi sprawami budzącymi niepokój sądownictwa ${ }^{30}$.

Jak już podniesiono, Rada ma również kompetencję do wskazywania trzech członków Komisji do spraw Nominacji Sędziowskich.

Rada spotyka się trzy razy do roku. Ponadto jej posiedzenie może być zwołane przez Lorda Naczelnego Sędziego po zasięgnięciu opinii Komitetu Wykonawczego Rady. Bieżące prace Rady są prowadzone przez Komitet Wykonawczy. Składa się on z siedmiu członków wybieranych przez Radę, a na jego czele stoi Starszy Sędzia Przewodniczący. Komitet zbiera się raz w miesiącu. Do jego kompetencji należy powoływanie grup roboczych oraz podkomisji, a także przedkładanie spraw na posiedzeniach plenarnych $\operatorname{Rady}^{31}$.

\section{SKŁAD RADY SĘDZIOWSKIEJ}

Skład Rady nie jest określony żadnymi powszechnie obowiązującymi przepisami prawa. Wynika on z reguł przyjętych przez samą Radę oraz z praktyki ustrojowej utrwalonej w ciągu ostatnich kilkunastu lat jej działalności. Ważnym elementem tej praktyki jest troska o zagwarantowanie udziału w Radzie przedstawicielom wszystkich szczebli sądownictwa oraz różnych organów zaliczanych do szeroko rozumianej władzy sądowniczej.

${ }^{30}$ Zob. Judges' Council Annual Report 2009, s. 16, https://www.judiciary.uk/wp-content/uploads/JCO/Documents/Reports/judges_council_annual_report_2009.pdf (dostęp: 11.06.2019).

31 Ibidem, s. 7, 17. 
Zgodnie ze statutem w skład Rady z urzędu wchodzą: Lord Naczelny Sędzia (Lord Chief Justice), Mistrz Rejestru (Master of Rolls), Przewodniczący Wydziału Ławy Królewskiej w Wysokim Trybunale (President of the Queen's Bench Division), Przewodniczący Wydziału Rodzinnego w Wysokim Trybunale (President of the Family Division and Head of Family Justice), Kanclerz Wysokiego Trybunału (Chancellor of the High Court), dyrektor Szkoły Sądownictwa (Chairman of the Judical College), Prezes Trybunałów Administracyjnych (Senior President of Tribunals), zastępca Przewodniczącego Wydziału Ławy Królewskiej w Wysokim Trybunale (Vice President of the Queen's Bench Division), Starszy Sędzia Przewodniczący (Senior Presiding Judge) ${ }^{32}$, wiceprzewodniczący Wydziału Karnego Sądu Apelacyjnego (The Vice-President of the Court of Appeal „Criminal Division”), zastępca Starszego Sędziego Przewodniczącego (Deputy Senior Presiding Judge).

Ponadto do Rady wchodzą członkowie wybierani na trzyletnią kadencję, reprezentujący szeroko rozumianą władzę sądowniczą. Obecnie są to: przewodniczący okręgu sądowego Sądu Koronnego (a Presiding Judge), sędzia Wydziału Kanclerskiego Wysokiego Trybunału (a High Court Judge of the Chancery Division), sędzia Wydziału Rodzinnego Wysokiego Trybunału (a High Court Judge of the Family Division), sędzia reprezentujący Stowarzyszenie Sędziów Wysokiego Trybunału (the High Court Judges' Association), Przewodniczący Królewskiej Rady Sędziów Okręgowych (The Council of Her Majesty’s Circuit Judges), honorowy sekretarz Królewskiej Rady Sędziów Okręgowych, sędzia rejonowy reprezentujący sądy pokoju (a District Judge), członek stowarzyszenia Sędziów Sekretarzy Wysokiego Trybunału (Association of High Court Masters), przewodniczący Stowarzyszenia Sędziów Rejonowych Jej Królewskiej Mości (Association of Her Majesty’s District Judges), honorowy sekretarz Królewskiej Rady Sędziów Rejonowych, sędzia reprezentujący wyższe trybunały administracyjne (a Senior Tribunal Judge), dwóch sędziów reprezentujących trybunały administracyjne (a Tribunal Judge), członek Stowarzyszenia Sędziów Pokoju (Magistrates' Association) oraz sędzia — członek reprezentujący organ koordynujący pracę sędziów pokoju (Magistrates' Leadership Executive). Dodatkowo status tak zwanych co-opted members mają: przedstawiciel Europejskiej Sieci Rad Sądownictwa (the European Network of Councils for the Judiciary), sądowy członek zarządu Służby Sądów i Trybunałów Jej Królewskiej Mości (the board of Her Majesty's Courts and Tribunals Service), jeden sędzia pracujący w niepełnym wymiarze godzin (a Fee-Paid Judge) oraz dwóch członków trybunałów administracyjnych. Dodatkowo członkiem Rady bez prawa głosu jest Szef Urzędu Sądownictwa (Chief Executive of the Judicial Office) ${ }^{33}$.

32 Sądzia orzekający w Sądzie Apelacyjnym, mianowany przez Lorda Naczelnego Sędziego. Do jego kompetencji należy sprawowanie nadzoru nad przewodniczącymi okręgów Sądów Koronnych. Zob. P. Mikuli, Rady sądownictwa w Zjednoczonym Królestwie..., s. 569.

33 https://www.judiciary.uk/wp-content/uploads/2019/06/jc-membership-may-2019.pdf (dostęp: 11.06.2019). 


\section{KOMISJA NOMINACYJNA}

W systemie prawnym Anglii i Walii funkcjonuje także inne ciało kolegialne, które można uznać za element systemu gwarancji niezależności sądownictwa. Jest nim Komisja Nominacyjna (Judicial Appointments Commission), której podstawową kompetencją jest udział w procesie wyłaniania kandydatów na sędziów.

W Zjednoczonym Królestwie mianowanie sędziów tradycyjnie uznawane było za prerogatywę monarchy ${ }^{34}$. Wraz z rozwojem parlamentarno-gabinetowego systemu rządów uprawnienie to w praktyce, na mocy konwenansów konstytucyjnych, przeszło pod kontrolę rządu i było realizowane przez lorda kanclerza i premiera. De facto do początku XXI wieku nominacje sędziowskie nie były regulowane przez normy ustawowe, lecz jedynie przez konwenanse oraz zasady kultury politycznej i prawnej. Brak transparentności reguł rządzących systemem nominacji oraz wpływ czynników politycznych spowodowały, że od drugiej połowy XX wieku coraz częściej podnosiły się głosy krytykujące obowiązujący system nominacji sędziowskich. W szczególności zwracano uwagę na bardzo dużą władzę lorda kanclerza $\mathrm{w}$ procesie nominacyjnym oraz nieformalne konsultacje z przedstawicielami środowisk sędziowskich ${ }^{35}$. Przeprowadzone reformy miały na celu obiektywizację kryteriów oceny kandydatów na sędziów oraz osłabienie wpływu politycznej egzekutywy na proces obsadzania urzędów sędziowskich.

Zasadniczą zmianę systemu nominacyjnego przyniosły dopiero reformy konstytucyjne przeprowadzone przez rząd Partii Pracy w latach 1997-2010 ${ }^{36}$. Wprowadzono wtedy kilka zasadniczych zmian do procesu wyłaniania sędziów. Zasadniczym elementem reformy było powołanie, oddzielne dla poszczególnych systemów prawnych w Królestwie, komisji do spraw nominacji sędziowskich, odpowiedzialnych za apolityczny i niezależny charakter selekcji kandydatów na urzędy sędziowskie. Dokonując zmian, postanowiono jednak nie zrywać całkowicie z wielowiekową tradycją wpływu egzekutywy na obsadę tych stanowisk. Wpływ ten jednak znacznie ograniczono ${ }^{37}$.

Komisja Nominacyjna została utworzona na podstawie ustawy The Constitutional Reform Act z 2005 roku $^{38}$. Obecnie w świetle art. 1 zał. 12 ustawy, w brzmieniu

34 English Public Law, red. D. Feldman, Oxford 2009, s. 288.

35 P. Mikuli, Powoływanie sędziów w Zjednoczonym Królestwie, [w:] Aktualne problemy konstytucji: księga jubileuszowa z okazji 40-lecia pracy naukowej profesora Bogusława Banaszaka, red. H. Babiuch, P. Kapusta, J. Michalska, Legnica 2017, s. 561.

36 Szerzej zob. P. Mikuli, Reformy ustrojowe w Zjednoczonym Królestwie w pierwszych latach XXI w., [w:] Aktualne problemy reform konstytucyjnych, red. S. Bożek, Białystok 2013.

37 P. Biskup, P. Mikuli, Zjednoczone Królestwo Wielkiej Brytanii i Irlandii Pótnocnej, [w:] Status prawny sędziego we wspótczesnych systemach politycznych, red. P. Mikuli, Koszalin-Gdańsk 2013, s. 36-37.

38 Szerzej zob. K. Malleson, The New Judicial Appointments Commission in England and Wales: New Wine in New Bottles?, [w:] Appointing Judges in an Age of Judicial Power: Critical Perspectives from around the World, red. K. Malleson, P.H. Russell, Toronto-Buffalo-London 2006, s. 39-55. 
nadanym mu przez art. 17 zał. 13 ustawy The Crime and Courts Act z 2013 roku Komisja ma składać się z takiej liczby członków, jaką ustali lord kanclerz w porozumieniu z lordem naczelnym sędzią. Zgodnie z rozporządzeniem The Judical Appointment Commission Regulations z 2013 roku składa się ona z przewodniczącego niewykonującego zawodu prawniczego oraz 14 członków powoływanych przez monarchę na wniosek lorda kanclerza. Spośród członków Komisji siedmiu musi być sędziami (judicial members) ${ }^{39}$, dwóch — reprezentować korporacje prawnicze Anglii i Walii (professional members), a kolejnych pięć miejsc ma być obsadzonych przez osoby niemające wykształcenia prawniczego (lay members), przy czym nie mogą to być urzędnicy Służby Cywilnej (Civil Service). Dwóch spośród sędziowskich członków Komisji wskazuje Rada Sędziowska dla Anglii i Walii, a jednego - Rada Sędziów Trybunałów (Tribunal Judges' Council). Pozostali członkowie Komisji są wyłaniani w postępowaniu konkursowym ${ }^{40}$. Kadencja członków wynosi pięć lat, z możliwością ponownego powołania, przy czym ta sama osoba może być członkiem komisji maksymalnie przez dziesięć lat ${ }^{41}$.

Zgodnie z ustawą z 2005 roku Komisja Nominacyjna odgrywa istotną rolę w procesie wyłaniania kandydatów na sędziów ${ }^{42}$. W zakresie urzędów sędziowskich w wyższych sądach dla Anglii i Walii Komisja wyłania specjalne panele konkursowe, które wskazują kandydata na wakujący urząd ${ }^{43}$. Ustawa utrzymała udział lorda kanclerza w procesie wypracowania ostatecznej kandydatury. Zgodnie z przyjętą procedurą może on przedstawioną kandydaturę przyjąć, odrzucić lub zwrócić się o ponowne jej rozważenie. W drugim etapie lord kanclerz może zatwierdzić wybór, odrzucić go, ale tylko wówczas gdy wcześniej prosił o ponowne rozpatrzenie sprawy albo, w sytuacji gdy wcześniej zawetował kandydaturę, może poprosić Komisję o ponowną decyzję. W sytuacji konieczności przeprowadzenia trzeciego etapu procedury selekcyjnej lord kanclerz musi zaakceptować kandydaturę albo - jeśli poprosił o ponowne rozważenie jakiejś kandydatury na pierwszym lub drugim etapie, a nie została ona wyłoniona — wskazać tę osobę ${ }^{44}$. W wypadku postepowań dotyczących obsady urzędów sędziowskich w niższych

39 Spośród pięciu sędziów wyłanianych w drodze konkursowej jeden musi być sędzią Sądu Apelacyjnego, jeden sędzią Wysokiego Trybunału, jeden sędzią Sądu Apelacyjnego lub Wysokiego Trybunału, jeden sędzią okręgowym oraz jeden sędzią rejonowym. Zob. G. Slapper, D. Kelly, op. cit., s. 457.

40 A. Gillespie, S. Weare, The English Legal System, Oxford 2017, s. 256-258; P. Mikuli, Sadownictwo w Zjednoczonym Królestwie..., s. 117-118.

41 P. Mikuli, Sądownictwo w Zjednoczonym Królestwie..., s. 118 n.

42 Szerzej na temat powoływania sędziów w Anglii i Walii zob. P. Mikuli, Powoływanie sędziów..., s. 561 n.; idem, Sądownictwo w Zjednoczonym Królestwie..., s. 99 n.

43 Zasady powoływania paneli konkursowych na najwyższe stanowiska sądowe są ustalane przez lorda kanclerza za zgodą lorda naczelnego sędziego.

44 P. Mikuli, Sądownictwo w Zjednoczonym Królestwie..., s. 102-103. 
sądach uprawnienie do odrzucenia kandydatury lub zwrócenia się o ponowne jej rozważenie przysługuje lordowi naczelnemu sędziemu ${ }^{45}$.

\section{PODSUMOWANIE}

Cechą charakterystyczną Rady Sędziowskiej jest jej ograniczona pozycja ustrojowa. Nie ma ona zakotwiczenia w prawie stanowionym i pełni jedynie funkcję ciała doradczego lorda naczelnego sędziego, który stoi na czele sądownictwa Anglii i Walii. Rada jest swego rodzaju organem samorządu sędziowskiego, reprezentującego sędziów różnych szczebli wymiaru sprawiedliwości. Znaczącą jej kompetencją jest $\mathrm{z}$ całą pewnością uprawnienie do uchwalania zasad etyki sędziowskiej. Jedynie niewielki udział w procesie powoływania sędziów oraz brak uprawnień dyscyplinarnych powoduje, że Rada ma ograniczone możliwości wpływania na funkcjonowanie wymiaru sprawiedliwości w Anglii i Walii. Dużo większe znaczenie w systemie sądowniczym Anglii i Walii ma Komisja Nominacyjna. Jej powołanie było elementem ograniczenia wpływów egzekutywy na proces obsadzania urzędów sędziowskich i niewątpliwie umocniło zasadę niezależności sądownictwa.

\section{JUDGES' COUNCIL AND JUDICIAL APPOINTMENT COMMISSION}

\section{Summary}

The judiciary in the United Kingdom is a phenomenon in Europe. Despite the fact that the role of judges in the common law system was significantly greater than in continental law systems, the British system lacked formal, institutional safeguards of the independence of the courts and the independence of judges. This principle was seen as a constitutional convention. The Judges' Council, being the representation of judges, had only the status of an internal judicial body and an advisory role to the Lord Chief Justice. The reforms of the justice system introduced at the beginning of the 20th century, including the establishment of the Judicial Appointments Commission, undoubtedly influenced the strengthening of the independence of the courts against the executive and increased the influence of the judicial community on the appointment system of judicial offices in England and Wales.

Keywords: Judges' Council, Judicial Appointment Commission, judiciary, independence of the judiciary

45 Ibidem, s. 120. 


\section{BIBLIOGRAFIA}

Banasik K., Przyszłość angielskiego prawa karnego, „Prokuratura i Prawo” 2013, nr 10.

Biskup P., Mikuli P., Zjednoczone Królestwo Wielkiej Brytanii i Irlandii Pótnocnej, [w:] Status prawny sędziego we współczesnych systemach politycznych, red. P. Mikuli, Koszalin-Gdańsk 2013.

Bradley K.D., Ewing K.D., Knight C.J.S., Constitutional and Administrative Law, London 2018.

Ching J.P.L., Taylor N.W., Smith, Bailey and Gunn on the Modern English Legal System, London 2007.

Delaney E., Searching for constitutional meaning in institutional design: The debate over judicial appointments in the United Kingdom, „International Journal of Constitutional Law” 2016, nr 3.

Drewry G., Blom-Cooper L., The Appellate Function, [w:] The House of Lords. Its Parliamentary and Judical Roles, red. B. Dickson, P. Carmichael, Oxford 1999.

English Public Law, red. D. Feldman, Oxford 2009.

Gee G., Hanzell R., Malleson K., O'Brien P., The Politics of Judicial Independence in the UK's Changing Constitution, Cambridge 2015.

Gibson B., Watkins M., The Magistrates' Court: An Introduction, Winchester 2009.

Gillespie A., Weare S., The English Legal System, Oxford 2017.

The Judicial House of Lords 1876-2009, red. L. Blom-Cooper, B. Dickson, G. Drewry, Oxford 2011.

Kelso A., Parliamentary Reform at Westminster, Manchester 2009.

Le Sueur A., The Conception of the UK's New Supreme Court, [w:] Building the UK's New Supreme Court. National and Comparative Perspectives, red. A. Le Sueur, Oxford 2004.

Malleson K., The New Judicial Appointments Commission in England and Wales: New Wine in New Bottles?, [w:] Appointing Judges in an Age of Judicial Power: Critical Perspectives from around the World, red. K. Malleson, P.H. Russell, Toronto-Buffalo-London 2006.

Martin J., The English Legal System, London 2007.

Michalak A., Pierwsze pięć lat działalności Sąu Najwyższego Zjednoczonego Królestwa Wielkiej Brytanii i Irlandii Pótnocnej, „Przegląd Sejmowy” 2015, nr 2.

Michalczuk C., Struktura sadownictwa karnego w Wielkiej Brytanii, „Prokuratura” 2005, nr 7-8.

Mikuli P., Powoływanie sędziów w Zjednoczonym Królestwie, [w:] Aktualne problemy konstytucji: ksiega jubileuszowa z okazji 40-lecia pracy naukowej profesora Bogusława Banaszaka, red. H. Babiuch, P. Kapusta, J. Michalska, Legnica 2017.

Mikuli P., Rady sądownictwa w Zjednoczonym Królestwie — zarys pozycji ustrojowej, [w:] Konstytucjonalizm — doktryny — nauki polityczne. Księga dedykowana Profesorowi Andrzejowi Ziębie, red. R. Kłosowicz, B. Kosowska-Gąstoł, Ł. Jakubiak, G.M. Kowalski, T. Wieciech, Kraków 2016.

Mikuli P., Reformy sądownictwa w Zjednoczonym Królestwie w latach 2005-2009, [w:] Od Thatcher do Blaira - Wielka Brytania na przetomie XX i XXI wieku, red. H. Toszek, T. Czapiewski, Szczecin 2010.

Mikuli P., Reformy ustrojowe w Zjednoczonym Królestwie w pierwszych latach XXI w., [w:] Aktualne problemy reform konstytucyjnych, red. S. Bożek, Białystok 2013.

Mikuli P., Sadownictwo w Zjednoczonym Królestwie. Wybrane zagadnienia ustrojowe, Kraków 2019.

Oliver D., Constitutionalism and the abolition of the Office of Lord Chancellor, „Parliamentary Affairs" 2004, nr 4.

Riddle H., Zara R., Essential Magistrates' Court Law, Winchester 2019.

Salzberger E.M., A positive analysis of the doctrine of separation of powers, or: Why do we have an independent judiciary?, „International Review of Law and Economics” 13, 1993.

Scott I., The Council of Judges in the Supreme Court of England and Wales, „Public Law” 1989.

Shears P., Stephenson G., James' Introduction to English Law, Oxford 2006. 
Slapper G., D. Kelly, The English Legal System, London 2017.

Thomas J., The Judges Council, „Public Law” 2005, 608.

Urbaniak K., Zasady podziału władzy w Wielkiej Brytanii, [w:] Zasady podziału władzy we wspótczesnych państwach europejskich, red. S. Grabowska, R. Grabowski, Rzeszów 2016.

Wilson G.P., Angielski sędzia, [w:] Problemy prawa angielskiego i europejskiego oraz reformy w Europie Środkowej (Polska, Wegry), red. K. Nowacki („Prawo” 272), Wrocław 2000. 